\title{
PIMAS
}

Jurnal Pengabdian Masyarakat

Homepage: http://ejournal.uhb.ac.id/index.php/PIMAS

\section{Peningkatan Motivasi Belajar Peserta Didik dengan Model Pembelajaran Berbasis IT di SMK Komputama Jeruklegi}

\author{
R Bagus Bambang Sumantri ${ }^{1}{ }^{*}$, Nurul Alfiah ${ }^{2}$ \\ ${ }^{1}$ Universitas Harapan Bangsa, Purwokerto, Indonesia \\ ${ }^{2}$ STMIK Komputama Majenang, Cilacap, Indonesia \\ 'bagusbambang@uhb.ac.id*; 2nurulalfiah@stmikkomputama.ac.id
}

Artikel History:

Received: 13-01-2022/ Received in revised form: 19-01-2022/ Accepted: 21-01-2022

\begin{abstract}
The learning process that runs in SMK Komputama Jeruklegi in the Covid-19 pandemic still uses conventional learning models, but in the current pandemic, teachers are required to be able to use online learning media. A teaching staff is also burdened by the task of administration that is very time-consuming sometimes the learning process is less effective and usually not implemented. That problem is the cause of the achievement of learning subjects are not achieved. For this reason, partners need a solution to solve learning problems that cannot be solved in the classroom and are not understood by students. So that with the e-learning training can provide learning services that can be implemented anytime and anywhere online. The method used is by the lecture method and direct practice using the Chamilo application where all trainees after getting the material delivered then practicing what has been given to be implemented. This community service activity can be concluded knowledge and understanding of the application of e-learning provided to the teaching staff who participated in the training can provide a new understanding of the existing learning model that can be used to increase the learning motivation of learners in the learning process in the classroom, and in the end the school has a new learning concept that can be used as a learning model in SMK Komputama Jeruklegi.
\end{abstract}

\section{Keywords : e-learning, online, Chamilo}

\begin{abstract}
ABSTRAK
Proses pembelajaran yang berjalan di SMK Komputama Jeruklegi di masa pandemi Covid-19 masih menggunakan model pembelajaran konvensional, namun di masa pandemi saat ini tenaga pengajar dituntut untuk mampu menggunakan media pembelajaran online. Seorang tenaga pengajar juga di bebankan oleh tugas adminstrasi yang sangat menyita waktu terkadang proses pembelajaran itu kurang efektif bahkan biasanya tidak terlaksana. Masalah Itu menjadi penyebab capaian pembelajaran mata pelajaran tidak tercapai. Untuk itulah mitra membutuhkan sebuah solusi untuk menyelesaikan permasalahan pembelajarannya yang tidak dapat diselesaikan di dalam kelas dan kurang dimengerti oleh para siswa. Sehingga dengan adanya pelatihan $e$ learning dapat memberikan layanan pembelajaran yang dapat dilaksanakan kapan saja dan dimana saja secara online. Metode yang digunakan adalah dengan metode ceramah dan praktek langsung dengan menggunakan aplikasi Chamilo dimana semua peserta pelatihan setelah mendapatkan materi yang disampaikan kemudian mempraktekkan apa yang sudah diberikan untuk di implementasikan. Kegiatan pengabdian masyarakat ini dapat disimpulkan pengetahuan dan pemahaman tentang penerapan e-learning yang diberikan kepada para tenaga pengajar yang mengikuti pelatihan tersebut dapat memberikan pemahaman baru mengenai terdapatnya model pembelajaran yang dapat digunakan untuk meningkatkan motivasi belajar peserta didik dalam proses pembelajaran di kelas, dan pada akhirnya sekolah mempunyai suatu konsep pembelajaran baru yang dapat dijadikan model pembelajaran di SMK Komputama Jeruklegi.
\end{abstract}

Kata kunci : e-learning, online, Chamilo

*Corresponding author. Tel.: +62856-7444-414

Email: bagusbambang@uhb@ac.id 


\section{PENDAhuluan}

Pertumbuhan teknologi serta informasi yang terjadi di negara ini membawa dampak positif bagi dunia pendidikan. Khususnya teknologi komputer dan internet baik dalam hal perangkat keras maupun perangkat lunak, memberikan banyak pilihan bagi dunia pendidikan untuk menunjang dan mempermudah proses pembelajaran. Perkembangan teknologi informasi banyak digunakan untuk membantu proses aktivitas manusia. Di dunia pendidikanlah kehadiran teknologi informasi menjadi salah satu pilihan untuk menyelenggarakan program pendidikan. Salah satu manfaat internet dalam bentuk media pembelajaran berbasis web merupakan salah satu bentuk e-learning yang saat ini sedang populer dikembangkan dan digunakan oleh lembaga pendidikan. Penggunaan teknologi informasi pada pembelajaran dapat memberikan pengaruh yang baik jika siswa bisa mengontrol penggunaan teknologi informasi tersebut. Pemanfataan teknologi informasi dalam pembelajaran daring dapat dilakukan dengan berbegai media, seperti Zoom Meting, pesan singkat (WA), media visual atau audio visual. Namun saat ini teknologi informasi yang banyak digunakan oleh tenaga pengajar dalam pembelajran daring di sekolah yaitu dengan menggunakan teknologi HP yaitu melalui pesan suara, pesan singkat (WA) dan juga zoom meting (Farell et al., 2021).

Dalam penyajiannya e-learning berbasis web ini bisa menjadi lebih interaktif dan menarik selain itu sistem e-learning ini tidak memiliki batasan akses, inilah yang memungkinkan pembelajaran bisa dilakukan lebih banyak waktu (Lestariningsih, 2016). Disisi lain e-learning dapat diartikan pula sebagai suatu sistem dalam pembelajaran yang mengacu pada penggunaan teknologi informasi yang dapat meningkatkan pengetahuan, minat belajar dan keterampilan dengan karakteristik-karakteristik seperti memanfaatkan jasa teknologi, memanfatkan keunggulan komputer, menggunakan bahan ajar yang bersifat mandiri, dan memanfaatkan jadwal belajar yang dapat dilihat pada komputer, serta memberikan fasilitas yang dapat diakses oleh pengajar dan peserta didik secara pribadi. E-learning telah membuka wawasan guru-guru untuk mengetahui dan memahami adanya beberapa aplikasi $e$ learning termasuk kelebihan dan kekurangan yang dimiliki oleh masing-masing aplikasi(Suhandiah et al., 2019)

Manfaat e-learning terdiri atas 4 hal, yaitu: (1) Meningkatkan interaksi pembelajaran antara peserta didik dengan tenaga pengajar (enhance interactivity); (2) Memungkinkan terjadinya interaksi pembelajaran dari mana dan kapan saja (time and place flexibility); (2) Menjangkau peserta didik dalam cakupan yang luas (potential to reach a global audience); (4) Mempermudah penyempurnaan dan penyimpanan materi pembelajaran (easy updating of content)(Yasa, 2017). e-learning lebih tepat ditujukan sebagai usaha untuk membuat sebuah transformasi proses belajar mengajar yang ada di sekolah ke dalam bentuk digital yang dijembatani oleh teknologi internet.

E-learning merupakan salah satu strategi sekolah untuk menghadapi persaingan kualitas pendidikan. Model pembelajaran menggunakan e-learning merupakan pembelajaran yang memberikan kesempatan kepada siswa untuk aktif dalam proses pembelajaran. Kegiatan pembelajaran yang menggunakan e-learning menuntut siswa menjadi lebih mandiri dan bertanggung jawab terhadap proses pembelajarannya, dikarenakan siswa dapta belajar di mana saja dan kapan saja. Salah satu keunggulan menggunakan media berbasis e-learning yaitu proses pembelajaran dapat dilakukan di mana pun dan kapan pun selama terkoneksi dengan internet (Widiantoro \& Rakhmawati, 2015). Proses pembelajaran yang menggunakan e-learning diharapkan terciptanya proses pembelajaran yang lebih efektif dan efisien, karena di dalamnya berisi media-media pembelajaran yang menarik (Supianti, 2018).

Implementasi e-learning ini telah banyak yang mengimplementasikannya, seperti yang dilakukan oleh (Susilo, B, Rusdi Efendi, 2018) membangun pembelajaran berbasis web (E-Learning) bagi tenaga pengajar sekolah dasar pinggiran Kecamatan Muara Bangkahulu Kota Bengkulu(Wijaya, 2012). Manfaat penerapan e-learning dalam upaya untuk meningkatkan kualitas pendidikan di sekolah dalam hal ini SMK Komputama Jeruklegi menjadi sudut pandang penulis yang dijadikan objek dalam pelaksanaan pengabdian. Dengan adanya sistem pembelajaran e-learning yang dilaksanakan secara tepat di sekolah-sekolah dapat dinikmati oleh para siswa maupun tenaga pengajar itu sendiri untuk membantu siswa dalam menyelesaikan permasalahan pembelajaran yang tidak dapat diselesaikan di kelas dan kurang dimengerti oleh para siswa sehingga dengan adanya sistem $e$ learning dapat memberikan layanan belajar yang terbaik dan tercepat. Penerapan ini merupakan sebuah wujud pembangunan berkelanjutan dalam bidang pendidikan tetapi juga dikembangkan untuk 
seterusnya karena ilmu pengetahuan dan informasi yang diterima siswa harus selalu berkembang. Dengan penerapan ini, diharapkan setiap individu yang berada di sekolah baik siswa maupun tenaga pengajar mampu berkompetisi dalam persaingan pendidikan di Indonesia yang semakin ketat bahkan dalam skala nasional bahkan internasional. Namun di pendidikan sekarang khususnya SMK Komputama Jeruklegi pada kenyataannya belum sepenuhnya siswa dan tenaga pengajar menggunakan sistem e-learning.

SMK Komputama Jeruklegi adalah salah satu SMK swasta yang terletak di wilayah Kabupaten Cilacap di kecamatan jeruklegi atau lebih tepatnya terletak di jalan Jeruklegi-Wangon. Model pembelajaran di SMK Komputama Jeruklegi sebagian besar masih menggunakan media pembelajaran buku pegangan atau dengan metode ceramah. Antara tenaga pengajar dan siswa belum mamanfaatkan secara maksimal penggunaan media teknologi dalam proses belajar mengajar. Pemanfaatan internat yang digunakan hampir seluruh siswa dan tenaga pengajar akan lebih memudahkan dalam teknik pembelajaran berbasis teknologi. Oleh karena itu perlu adanya pelatihan penggunakan media pembelajaran berbasis teknologi. Adapun kendala yang berkenaan dengan penggunaan teknologi yaitu kurangnya pengetahuan tenaga pengajar tentang media pembelajaran berbasis teknologi dan kurangnya motivasi dari tenaga pengajar untuk mempelajari penerapan teknologi dalam pembelajaran. Metode konvensional yang diterapkan oleh tenaga pengajar di SMK Komputama Jeruklegi, membuat peserta didik lebih cepat merasa bosan sehingga kurang konsentrasi terhadap pelajaran yang diajarkan. Dengan adanya permasalahan tersebut diatas, maka diperlukan pelatihan dan pendampingan bagaimana penggunaan teknologi dalam proses belajar mengajar yang dilakukan oleh dosen Universitas Harapan Bangsa dalam program pengabdian masyarakat. Tujuan utama program pengabdian masyarakat ini adalah untuk memberikan pelatihan dan pendampingan media pembelajaran berbasis IT untuk meningkatkan motivasi belajar peserta didik.

\section{METODE PELAKSANAAN KEGIATAN}

\subsection{Tahap Persiapan}

Pelaksanaan kegiatan pengabdian kepada masyarakat ini diawali dengan persiapan sebaik mungkin agar pelaksanaannya dapat berjalan lancar sesuai yang diharapkan. Untuk itu, persiapan yang dilakukan diawali dengan tinjauan ke lapangan, berkunjung ke SMK Komputama Jeruklegi untuk mengetahui kondisi tenaga pengajar dan tenaga pendidik yang merupakan calon peserta dan kesediaan untuk memfasilitasi kegiatan, menyiapkan peralatan-peralatan yang akan digunakan, menyiapkan aplikasi dan bahan pembelajaran yang akan digunakan. Pelaksanaan kegiatan meliputi: 1.Registrasi peserta; pembukaan acara; dan penjelasan pelaksanaan kegiatan. 2. Pemberian materi singkat diselingi tanya jawab yang meliputi pengantar tentang pelatihan penggunaan IT dalam Pembelajaran Bagi Tenaga pengajar SMK Komputama Jeruklegi untuk meningkatkan motivasi belajar peserta didik, 3 . Demonstrasi oleh tim kegiatan 4. Praktik diselingi tanya jawab, cara perencanaan pembuatan, dan mengaplikasikan 5. Evaluasi. Pelaksanaan evaluasi dimaksudkan untuk mengetahui efektivitas dan pemahaman kegiatan pengabdian kepada masyarakat yang dilaksanakan, yaitu untuk mengetahui sejauhmana tujuan yang ditetapkan sebelumnya telah tercapai. Evaluasi dilaksanakan sebanyak 3 tahap yaitu evaluasi tahap awal, evaluasi tahap proses, dan evaluasi tahap akhir. Evaluasi tahap awal dilakukan untuk mengetahui kondisi awal dan kemampuan serta kebutuhan peserta diberikan pertanyaan tentang materi sebelum menggunakan e-learning. Evaluasi tahap proses dilakukan pada saat pelatihan berlangsung untuk mengetahui sejauhmana pelaksanaan kegiatan dapat diikuti dan dipahami oleh peserta. Evaluasi tahap akhir dilakukan setelah kegiatan praktek selesai untuk mengetahui sejauh mana efektivitas pelaksanaan kegiatan dan bagaimana tingkat keberhasilan pelatihan yang diperoleh oleh peserta kegiatan.

\subsection{Metode}

Metode yang di gunakan untuk mengatasi permasalahan yang saat ini muncul dan dihadapi oleh SMK Komputama Jeruklegi adalah sebagai berikut : 


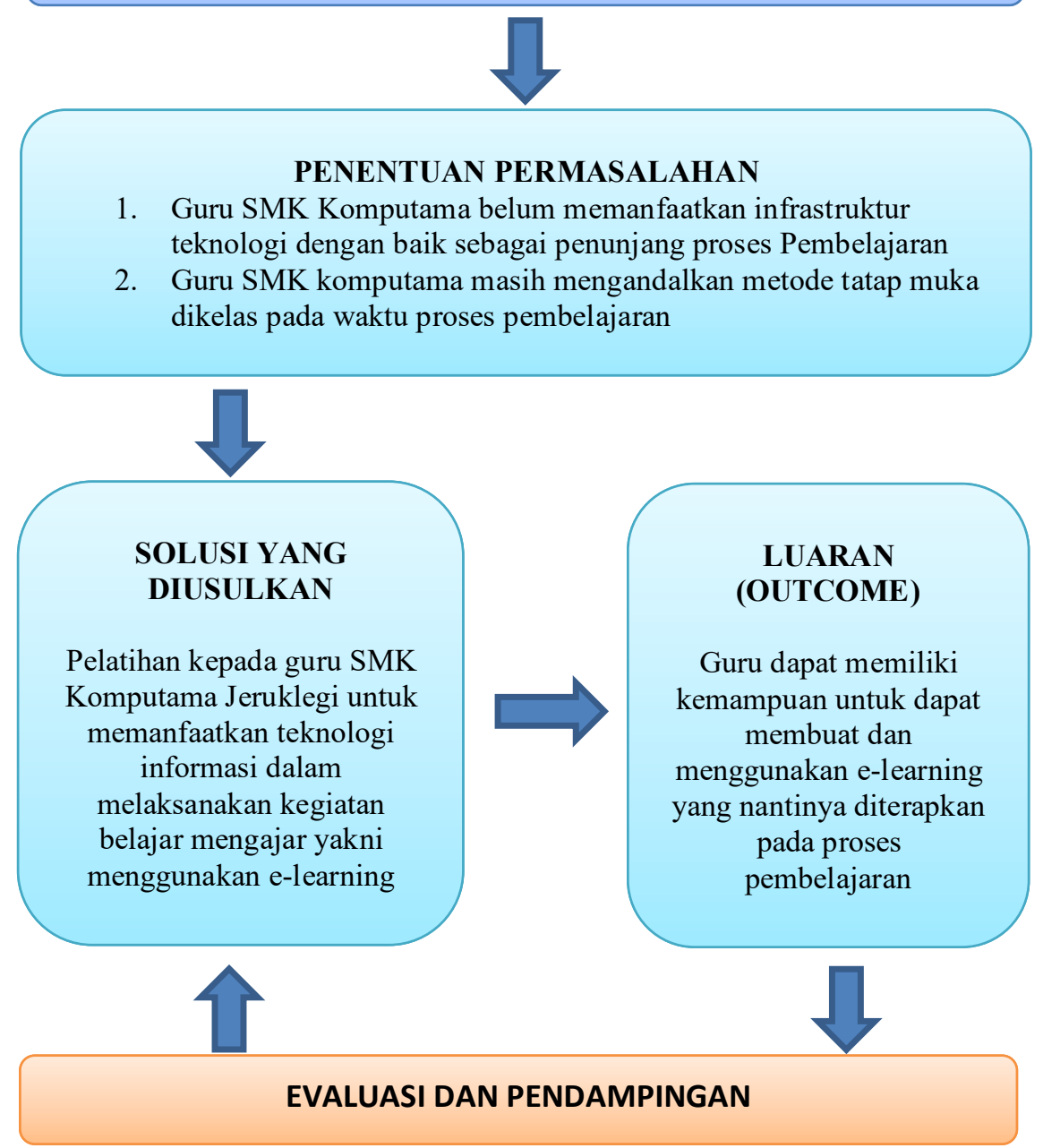

Gambar 1. Tahapan metode yang digunakan

Pada gambar 1 diperlihatkan tahapan-tahapan metode yang diusulkan pada kegiatan PKM yang dilaksanakan sebagai solusi permasalahan yang dihadapi oleh mitra. Tahapan - tahapan yang digunakan adalah sebagai berikut:

1) Analisis Situasi dan Survei

Tahapan ini adalah tahapan pertama yang dilakukan sebelum kegiatan dilakukan. Pada tahap ini survey dilakukan kepada mitra dalam hal ini yaitu SMK Komputama Jeruklegi, setelah itu dilakukan analisis terkait dengan situasi yang saat ini sedang terjadi. Pada tahapan analisis situasi ditemukan beberapa permasalahan yang dihadapi oleh mitra.

2) Penentuan Permasalahan Prioritas

Berdasarkan hasil kesepakatan bersama antara tim PKM dan mitra ditentukanlah permasalahan prioritas yang harus segera dicarikan solusinya sehingga pada tahapan ini permasalahan utama sudah ditentukan untuk diselesaikan.

3) Solusi yang diusulkan

Tahapan ini adalah penentuan solusi yang disusulkan oleh tim pelaksana PKM kepada mitra, sesuai dengan kesepakatan maka solusi yang diusulkan dijalankan sesuai dengan konsep dan metode yang telah ditentukan oleh tim pelaksana PKM dan disetujui oleh mitra. 
4) Luaran (Outcome)

Setelah solusi telah ditentukan, capaian yang diharapkan pada kegiatan PKM ini adalah Tenaga pengajar memiliki kemampuan untuk dapat membuat media pembelajaran dengan menggunakan e-learning sehingga dapat diterapkan pada proses pembelajaran di kelas kepada siswa.

5) Evaluasi dan Pendampingan

Untuk mengukur sejauh mana tingkat keberhasilan dari kegiatan PKM yang telah dilaksanakan maka dilakukan evaluai dan pendampingan. Tahapan ini dilakukan untuk mensinkronkan antara tujuan dan harapan dari kegiatan PKM ini agar sesuai dengan capaian atau luaran yang telah ditentukan. Evaluasi dilakukan dengan cara memberikan peserta pelatihan soal pre-test sebelum pelatihan. Tahap Evaluation berisi penilaian media pembelajaran yang sudah dikembangkan dan melakukan perbaikan berdasarkan saran dari para ahli (Nurbaiti \& Arcana, 2019).

\subsection{Lokasi dan Pelaksanaan Kegiatan}

Pelaksanaan kegiatan dilaksanakan di SMK Komputama Jeruklegi dengan sasaran 19 tenaga pengajar dan 13 staf pengajar. Kegiatan dilaksanakan pada tanggal 28 September 2021 di ruang kelas XI. Media yang digunakan dalam pembelajaran adalah aplikasi Chamilo. Chamilo sendiri adalah aplikasi berbasis internet (open source) yang mudah digunakan tetapi mempunyai fitur dan fasilitas yang memungkinkan untuk digunakan sebagai media pembelajaran e-learning selain itu chamilo mempunyai kelebihan yaitu 1 . Dukungan visual yang banyak membuat user lebih mudah memahami, dan inilah salah satu kelebihan Chamilo yang tidak dimiliki oleh E-Learning lainnya. 2. Chamilo lebih responsif jika dibandingkan dengan E-Learning lainnya. 3. Semua fitur Chamilo dalam pembuatan ELearning bisa diintegrasikan dengan aplikasi E-Learning lainnya, seperti Hot Potatoes. Moodle dan sebagainya sehingga dengan penggunaan media ini capaian dari pelaksanaan kegiatan PKM dapat tercapai sesuai dengan yang di harapkan.

\section{HASIL KEGIATAN DAN PEMBAHASAN}

\subsection{Pelaksanaan Kegiatan}

Kegiatan pelatihan dilaksanakan di SMK Komputama Jeruklegi yang di ikuti oleh tenaga pengajar dan tenaga pendidik. Kegiatan dibuka oleh kepala sekolah dihadiri oleh pembina yayasan. Kegiatan diawali dengan pemaparan materi dan dilanjutkan praktek secara langsung yang di ikuti oleh seluruh peserta kegiatan. Dari hasil pelatihan yang telah dilakukan, para peserta memiliki kemampuan untuk mempelajari dan menggunakan e-learning sesuai dengan user yang telah dimiliki peserta.

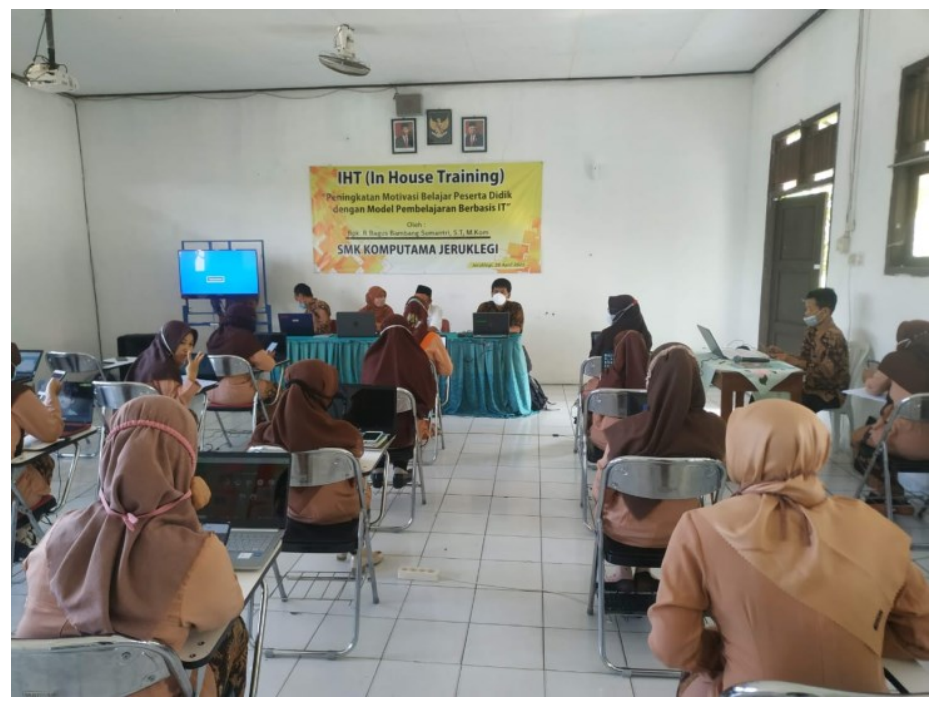

Gambar 2. Pemaparan materi 
Pada gambar 2 diperlihatkan situasi pada saat pemaparan materi yang disampaikan oleh fasilitator pengabdian kepada masyarakat dan diikuti oleh tenaga pengajar dan tenaga pendidik.
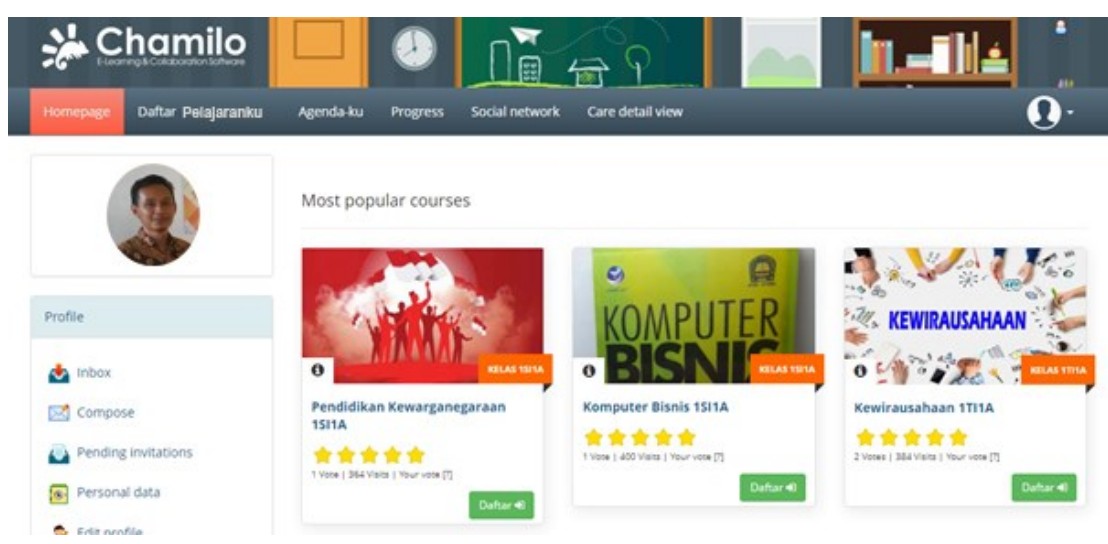

Gambar 3 Screenshoot Chamilo salah satu tenaga pengajar peserta pelatihan

Pada gambar 3 merupakan salah satu contoh tampilan dari interface e-learning yang telah dibuat oleh peserta pelatihan SMK Komputama Jeruklegi

\subsection{Evaluasi Hasil Pendampingan}

Evalusi digunakan untuk mengukur sejauhmana tingkat keberhasilan peserta dari pelatihan yang dilaksanakan. Penilaian pre-test dan post-test dilakukan sebagai bagian dari metode yang dilakukan. Materi pertanyaan yang diberikan kepada peserta pelatihan adalah pertanyaan-pertanyaan yang terkait dengan pengetahuan konsep e-learning dan pengoperasian aplikasi Chamilo, dengan jumlah pertanyaan yang diberikan adalah sebanyak 20 pertanyaan. Pada tabel 1 ditunjukkan hasil dari penilaian yang sudah dilakukan terhadap para peserta kegiatan.

Tabel 1 Hasil penilaian pre-test dan post-test peserta selama pelatihan

\begin{tabular}{rcccc}
\hline No & Kode Peserta & Nilai Pre-Test & Nilai Post-Test & Kenaikan \% \\
\hline 1 & S-01 & 30 & 70 & $133,33 \%$ \\
\hline 2 & S-02 & 40 & 60 & $50,00 \%$ \\
\hline 3 & S-03 & 45 & 75 & $66,67 \%$ \\
\hline 4 & S-04 & 30 & 85 & $183,33 \%$ \\
\hline 5 & S-05 & 45 & 85 & $88,89 \%$ \\
\hline 6 & S-06 & 55 & 80 & $45,45 \%$ \\
\hline 7 & S-07 & 65 & 75 & $15,38 \%$ \\
\hline 9 & S-08 & 50 & 85 & $70,00 \%$ \\
\hline 10 & S-09 & 50 & 65 & $30,00 \%$ \\
\hline 11 & S-10 & 30 & 65 & $116,67 \%$ \\
\hline 12 & S-12 & 40 & 90 & $125,00 \%$ \\
\hline 13 & S-13 & 35 & 75 & $114,29 \%$ \\
\hline 14 & S-14 & 55 & 80 & $77,78 \%$ \\
\hline 15 & S-15 & 30 & 90 & $80,00 \%$ \\
\hline 16 & S-16 & 35 & 70 & $133,33 \%$ \\
\hline 17 & S-17 & 60 & 75 & $114,29 \%$ \\
\hline 18 & S-18 & 25 & 60 & $33,33 \%$ \\
\hline & & $\mathbf{4 2 , 2 2}$ & $\mathbf{7 5 , 8 3}$ & $\mathbf{8 9 , 8 7 \%}$ \\
\hline
\end{tabular}


Pada tabel 1, kenaikan persentasi nilai dihitung dengan cara: Besar $=($ besar kenaikan $/$ nilai pretest X $100 \%$ ) sehingga didapatkan nilai rata-rata kenaikan sekitar $89,87 \%$.

\section{SIMPULAN}

Dari hasil kegiatan pengabdian pada masyarakat ini terdapat berberapa yang dapat disimpulkan diantaranya: (1) Pengetahuan dan pemahaman akan penerapan model pembelajaran Internet learning melalui media sosial yang diberikan kepada para Tenaga pengajar SMK Komputama Jeruklegi yang ikut pelatihan tersebut dapat memberikan pemahaman baru mengenai terdapatnya media pembelajaran alternatif yang bisa diguanakan dalam proses pembelajaran di kelas; (2) Sekolah SMK Komputama Jeruklegi akhirnya mempunyai suatu metode konsep model pembelajaran baru yang dapat dijadikan alternative pembelajaran. (3) Setelah Mengikuti pelatihan dan implementasi peserta mengalami kenaikan penguasaan materi rata-rata $89,87 \%$.

\section{SARAN}

Saran yang dapat diberikan adalah perlu adanya pelatihan yang berkelanjutan khusus bagi Tenaga pengajar SMK Komputama Jeruklegi sehingga dapat lebih memperdalam kembali mengenai internet learning khususnya dalam praktek penggunaannya sehingga motivasi belajar peserta didik meningkat.

\section{DAFTAR PUSTAKA}

Farell, G., Ambiyar, A., Simatupang, W., Giatman, M., \& Syahril, S. (2021). Analisis Efektivitas Pembelajaran Daring Pada SMK Dengan Metode Asynchronous dan Synchronous. Edukatif: Jurnal Ilmu Pendidikan, 3(4), 1185-1190. https://edukatif.org/index.php/edukatif/article/view/521

Lestariningsih. (2016). THE DEVELOPMENT OF E-LEARNING SOCIAL MEDIA BASE TO THE STUDY OF GROUP DYNAMIC IN STTIAA PACET MOJOKERTO. Angewandte Chemie International Edition, 6(11), 951-952., 424-440.

Nurbaiti, N., \& Arcana, I. N. (2019). Pengembangan YouTube Pembelajaran Persamaan Garis Singgung Lingkaran di SMA Menggunakan VideoScribe. UNION: Jurnal Ilmiah Pendidikan Matematika, 7(2), 227. https://doi.org/10.30738/union.v7i2.4057

Suhandiah, S., Sudarmaningtyas, P., \& Ayuningtyas, A. (2019). Pelatihan E-Learning Bagi Guru Untuk Optimalisasi Pembelajaran Generasi Z. Aksiologiya: Jurnal Pengabdian Kepada Masyarakat, 4(1), 108. https://doi.org/10.30651/aks.v4i1.3470

Supianti, I. I. (2018). Pemanfataan Teknologi Informasi dan Komunikasi (TIK) dalam Pembelajaran Matematika. MENDIDIK: Jurnal Kajian Pendidikan Dan Pengajaran, 4(1), 63-70. https://doi.org/10.30653/003.201841.44

Susilo, B, Rusdi Efendi, S. M. (2018). Membangun Pembelajara Berbasis Web (E-Learning) Bagi Guru Sekolah Dasar Pinggiran Kecamatan Muara Bangkahulu Kota Bengkulu. Berdikari: Jurnal Pengabdian Masyarakat Indonesia, 1(1), 21-26. https://doi.org/10.11594/bjpmi.01.01.03

Widiantoro, B., \& Rakhmawati, L. (2015). Pengembangan Media Pembelajaran E-Learning Berbasis Schoology Pada Kompetensi Dasar Memahami Model Atom Bahan Semikonduktor Di Smkn 1 Jetis. Jurnal Pendidikan Teknik Elektro, 04(2), 501-506.

Wijaya. (2012). Pengembangan model pembelajaran e-learning berbasis web dengan prinsip ePedagogy dalam meningkatkan hasil belajar. Jurnal Pendidikan Penabur, 20-27.

Yasa, A. D. (2017). Creative Writing Class Iv After Taught The Scientific Approach. ADRI International Journal Of Education Technology. 